\title{
Integrating Future Land Use Scenarios to Evaluate the Spatio-Temporal Dynamics of Landscape Ecological Security
}

\author{
Yi Lu, Xiangrong Wang, Yujing Xie *, Kun Li and Yiyang Xu \\ Department of Environmental Science and Engineering, Fudan University, Shanghai 200433, China; \\ lylois@163.com (Y.L.); xrxrwang@fudan.edu.cn (X.W.); likun211@126.com (K.L.); \\ yiyangxufd@fudan.edu.cn (Y.X.) \\ * Correspondence: xieyj@fudan.edu.cn; Tel.: +86-21-5566-4052 \\ Academic Editor: Vincenzo Torretta
}

Received: 19 October 2016; Accepted: 25 November 2016; Published: 30 November 2016

\begin{abstract}
Urban ecological security is the basic principle of national ecological security. However, analyses of the spatial and temporal dynamics of ecological security remain limited, especially those that consider different scenarios of urban development. In this study, an integrated method is proposed that combines the Conversion of Land Use and its Effects (CLUE-S) model with the Pressure-State-Response (P-S-R) framework to assess landscape ecological security (LES) in Huangshan City, China under two scenarios. Our results suggest the following conclusions: (1) the spatial and temporal dynamics of ecological security are closely related to the urbanization process; (2) although the average values of landscape ecological security are similar under different scenarios, the areas of relatively high security levels vary considerably; and (3) spatial heterogeneity in ecological security exists between different districts and counties, and the city center and its vicinity may face relatively serious declines in ecological security in the future. Overall, the proposed method not only illustrates the spatio-temporal dynamics of landscape ecological security under different scenarios but also reveals the anthropogenic effects on ecosystems by differentiating between causes, effects, and human responses at the landscape scale. This information is of great significance to decision-makers for future urban planning and management.
\end{abstract}

Keywords: landscape ecological security; scenarios; CLUE-S; Pressure-State-Response (P-S-R) framework; spatio-temporal dynamics

\section{Introduction}

Urbanization has profoundly changed land use around the globe [1]. Notable landscape fragmentation and decreased ecosystem stability have become common as various elements and structures have been created in original ecological landscapes [2-4]. As a result, many ecological and environmental problems have worsened, such as global climate change [5], urban flooding [6], and surface water pollution [7]. The increased vulnerability of urban landscapes to large-scale environmental changes that arise from urbanization threaten the ecological security in urbanized areas [8]. Therefore, it is important to determine the effects of urban land use change on ecosystems and quantify the relationships between urban land dynamics and ecological security. This knowledge can improve urban planning and policy making for sustainable urban development $[9,10]$.

Ecological security was first proposed by the government of the United States [11], and it included natural, economic, and socio-ecological security, as well as human well-being [12,13]. It refers to an ecological and environmental state that is indispensable to the safe development of a society or country [14,15]. The theory of ecological security has gradually matured [16]. Recently, a variety of 
studies have focused on landscape ecological security (LES) and relative evaluation approaches for it [17-19], as spatial landscape analyses can be performed to understand complex ecological processes and link land use and its ecological impacts [20]. It is reported that the provision of ecosystem services could be significantly impaired by the landscape fragmentation, configuration, and diversity [21]. Urban growth at an unprecedented scale and rate, has given rise to substantial impacts on the landscape pattern suggested by the landscape metric analyses [22]. The Pressure-State-Response framework (P-S-R) and its evolved frameworks, have been utilized in landscape ecological security evaluations [23-26], due to its capacity for presenting information in a causal manner that differentiates between causes, effects, and human responses and reflects the extent of anthropogenic impacts on ecological systems. For instance, Driver-Pressure-State-Impact-Response (D-P-S-I-R) framework applied in coastal megacities indicated that the factors, including rapid development, high population densities and high consumption rate have significant impact on environment degradation [27]. These works are significant for analyzing the spatial and temporal dynamics of landscape ecological security.

Urban areas are highly intricate and dynamic ecosystems comprising natural, social, and economic entities that influence urban ecological security [28,29]. These factors must be considered in evaluations of landscape ecological security in urban areas, which would be significant in supporting decision-making for future urban planning and management. Some models and methods have been used to describe the dynamics of ecological security, such as the CA (Cellular automaton) model and early warning method $[25,30]$. Nevertheless, evaluations of ecological security under different scenarios of urban development remain limited. However, scenario analysis can provide useful insight for exploring the uncertainties and dynamics of urban development.

Scenario analysis can be used to evaluate future ecological security through exploring and comparing the consequences of assumed changes under different scenarios of urban development [31]. Thus, the approach can help urban planners improve sustainable development and balance rapid urbanization and environmental protection [32]. Land use simulation is a key step in scenario analysis. Various models of land use simulation have been developed, such as Markov chains [33], system dynamics (SD) models [34], cellular automata (CA) models [35], and the Conversion of Land Use and its Effects at Small regional extent (CLUE-S) model [36]. The CLUE-S model can effectively simulate complex processes by accounting for both socio-economic and natural factors. Additionally, it explores the competition between different types of land use based on system theory and produces spatially explicit distributions of land use [37]. It has been widely used in landscape studies in various regions around the world, such as mountainous areas, hydrologic basins, cultivated areas, mining cities, and urban agglomerations [32,38-41]. However, the CLUE-S model could not provide the land use demands, which should be calculated by other models. Thus, the Markov model is usually combined with CLUE-S model to simulate spatial-temporal land use changes under different scenarios [42]. The Markov-CLUE-S model is able to simulate changes of different land use types simultaneously, and integrate land use policies and urban plans into its setting, which could provide useful information for urban management. Ecological security is affected by complex social and natural processes, and it is closely related to land use change. Thus, combining the CLUE-S model with landscape spatial analyses may be appropriate for evaluating landscape ecological security by illustrating the associated spatial and temporal dynamics.

In this study, Huangshan City in Anhui Province, China, is selected as a case study to illustrate the integrated method of combining the CLUE-S model and the Pressure-State-Response (P-S-R) framework to evaluate landscape ecological security. Huangshan City experienced rapid urbanization from 2000 to 2010, and the future ecological security in 2020 is simulated and assessed using our proposed method. The principal objectives of this study are as follows: (1) couple the CLUE-S model and P-S-R framework at the landscape scale to create a new approach for ecological security evaluation; (2) describe the dynamic spatial and temporal changes associated with landscape ecological security; (3) determine the anthropogenic impacts on ecosystems by differentiating among causes, effects, and human responses; and (4) provide useful information for urban planners and decision makers. 


\section{Materials and Methods}

\subsection{Study Area}

Huangshan City, which is located in southern Anhui Province, China $\left(117^{\circ} 12^{\prime}-118^{\circ} 53^{\prime} \mathrm{E}\right.$, $29^{\circ} 24^{\prime}-30^{\circ} 31^{\prime} \mathrm{N}$ ), comprises 4 counties (She, XiuNing, Yi, and QiMeng), 3 districts (TunXi, HuangShan, and HuiZhou) and 101 towns. It covers approximately $9776.01 \mathrm{~km}^{2}$, and $90 \%$ of the total area is hilly and mountainous terrain, with an elevation ranging from $-3 \mathrm{~m}$ to $1826 \mathrm{~m}$ [43] (see Figure 1). Huangshan City has a typical temperate humid monsoon climate, with annual average temperature at approximately $15-16{ }^{\circ} \mathrm{C}$ and annual average rainfall at approximately $1670 \mathrm{~mm}$, both of which exhibit clear seasonal variations. The dominate soil types are yellowish red soil and paddy soil, which are suitable for forestry and tea and rice cultivation [44].

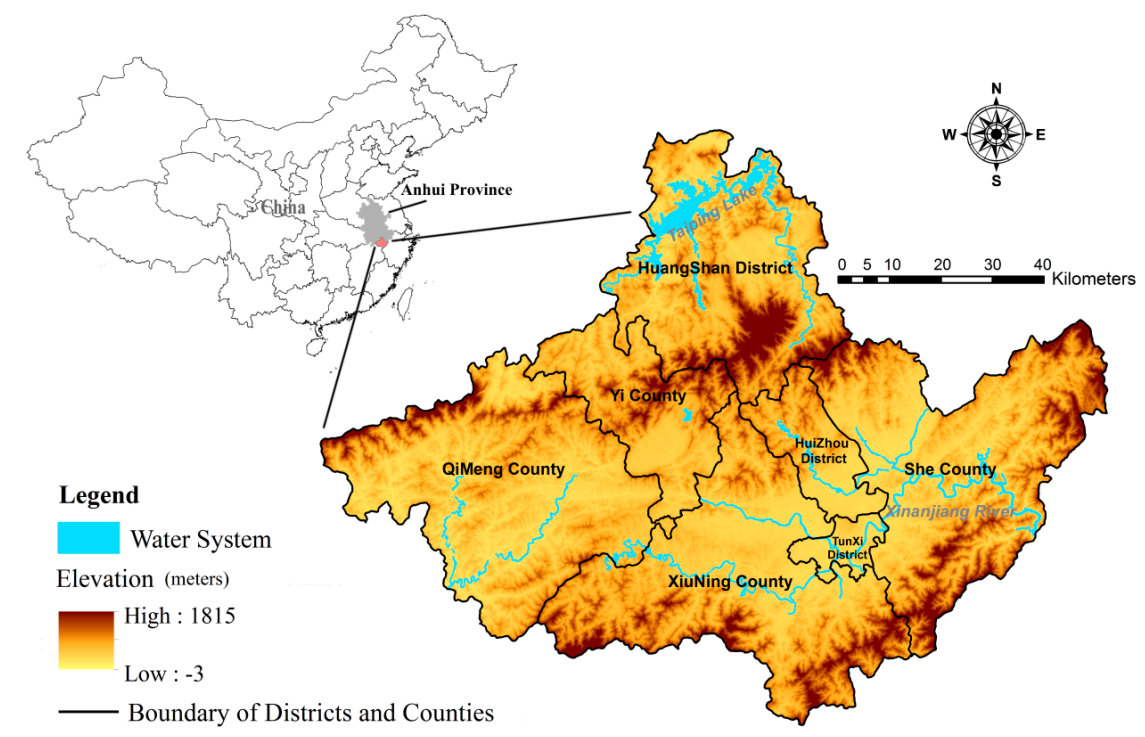

Figure 1. Location of the study area.

The Xinanjiang River and Taiping Lake are the main water resources in Huangshan City. The river dissects the urban area from east to west, and the lake is located in the northern part of the study area. Both are considered national regions of water resource conservation $[45,46]$. The primary land use type in the study area is forestland, which covers over $80 \%$ of the area. Due to rapid urbanization, the area of construction land has expanded, and the population has considerably increased since 2000. Huangshan City is also one of the most famous tourism cities in China, and 1.95 million tourists visited the city in 2015, generating close to 40.07 billion CNY in revenue [47]. However, these pressures from economic and social development have resulted in significant changes in land use and the associated landscape patterns, and these changes are threating the ecological security of the region. Therefore, simulating urban landscape patterns and forecasting the urban ecological security can provide insight into future development and planning in Huangshan City.

\subsection{Data Processing}

The land use data used in this study were obtained by remote sensing interpretation from Landsat TM/ETM imagery (from 2000) and HJ-1 CCD imagery (from 2010) at a resolution of $30 \mathrm{~m}$. The global accuracies of the 2000 and 2010 images were $86 \%$ and $94 \%$, respectively. Based on the land use classification of the Intergovernmental Panel on Climate Change (IPCC) [48] and the objectives of this study, six types of land use were classified in this analysis: shrubland, forestland, construction land, farmland, grassland, wetland, and bareland. Other spatial and non-spatial data used in this study are shown in Table 1 . In addition, preliminary analyses of different grid resolutions (including 
$50 \mathrm{~m} \times 50 \mathrm{~m}, 100 \mathrm{~m} \times 100 \mathrm{~m}, 200 \mathrm{~m} \times 200 \mathrm{~m}$, and $500 \mathrm{~m} \times 500 \mathrm{~m}$ ) in the CLUE-S model indicated that the most suitable grid resolution was $100 \mathrm{~m} \times 100 \mathrm{~m}$ in Huangshan City. Thus, all types of data were transformed to this grid resolution using the same projection coordinates.

Table 1. List of input data used in the analyses.

\begin{tabular}{|c|c|c|c|}
\hline Variable & Description & Resolution & Source \\
\hline DEM & $\begin{array}{l}\text { Spatial data used to generate } \\
\text { the elevation, aspect, and slope }\end{array}$ & $30 \mathrm{~m}$ & $\begin{array}{c}\text { The Geospatial Data Cloud of } \\
\text { the Chinese Academy of } \\
\text { Science [49] }\end{array}$ \\
\hline \multirow{2}{*}{$\begin{array}{l}\text { Administrative } \\
\text { boundaries }\end{array}$} & \multirow{2}{*}{$\begin{array}{l}\text { Spatial data at the national, } \\
\text { provincial, and city levels used } \\
\text { to generate the administrative } \\
\text { map of Huangshan City }\end{array}$} & $\begin{array}{c}\text { Cartographic scale } \\
\text { of } 1: 400,000 \text { at the national and } \\
\text { provincial levels }\end{array}$ & $\begin{array}{l}\text { The National Geometrics } \\
\text { Center of China (NGCC) [50] }\end{array}$ \\
\hline & & $\begin{array}{c}\text { Cartographic scale } \\
\text { of } 1: 200,000 \text { at the city level }\end{array}$ & $\begin{array}{l}\text { The Department of } \\
\text { Urban-Rural Planning, } \\
\text { Huangshan City }\end{array}$ \\
\hline Roads & $\begin{array}{l}\text { Level 1-2 traffic network } \\
\text { distribution } \\
\text { (highway and railway) }\end{array}$ & Cartographic scale of $1: 200,000$ & Same as above \\
\hline Rivers & River network distribution & Same as above & Same as above \\
\hline Administrative center & $\begin{array}{l}\text { Level 1-3 administrative center } \\
\text { distribution (urban, town, and } \\
\text { rural settlement centers) }\end{array}$ & Same as above & Same as above \\
\hline Population & $\begin{array}{l}\text { Seven counties and towns from } \\
2000-2010\end{array}$ & / & $\begin{array}{c}\text { Huangshan City Statistical } \\
\text { Yearbooks }\end{array}$ \\
\hline GDP & $\begin{array}{l}\text { Seven counties and towns from } \\
\qquad 2000-2010\end{array}$ & / & Same as above \\
\hline $\begin{array}{l}\text { Ecological function } \\
\text { zones }\end{array}$ & $\begin{array}{l}\text { Map used to determine the } \\
\text { implementation degree }\end{array}$ & Cartographic scale of 1:10,000 & $\begin{array}{c}\text { The Department of } \\
\text { Environmental Protection, } \\
\text { Huangshan City }\end{array}$ \\
\hline
\end{tabular}

\subsection{Methods}

\subsubsection{Scenario Assumptions}

Scenario analysis provides an approach for studying alternative future land systems through projections [51]. Two scenarios, named the natural trend scenario (NTS) and ecological protection scenario (EPS), are assumed to examine the land use change and landscape ecological security in 2020. Under the NTS, the changes in land use and population in Huangshan City are predicted according to historical development trends from 2000 to 2010. Under the EPS, we assume that land use change in 2020 is affected by state and local policies that focus on ecological and environmental protection. Due to the assumed decrease in urbanization, the rate of expansion of construction land will decrease. The area of wood land, including shrubland and forestland, will increase based on the state policy of "Grain for Green" [52], and the bareland area will decrease based on the state policy of "Land Reclamation" [53]. In addition, wetland areas will be preserved, and areas within $300 \mathrm{~m}$ of the Xinanjiang River and its branches and within $500 \mathrm{~m}$ of Taiping Lake are deemed water protection regions to strictly control the land use transition [32]. According to "Urban Planning of Huangshan City (2000-2020)", the population growth rate will decrease to lower than $50 \%$ of the historical growth rate from 2000 to 2010.

\subsubsection{Specific Settings in the CLUE-S Model}

The CLUE-S model includes a non-spatial demand module and a spatially explicit module of land use allocation. In this study, the following three elements are considered: land use demands, location characteristics and suitability, and specific conversion settings for each land use type [54]. The Kappa coefficient [55] is used to validate the accuracy of the simulated results prior to the 2020 simulation by comparing the initial simulation results to the actual land use map from 2010. 
(1) Land Use Demands

The Markov model is used to predict the land use demands in 2020 based on the probability matrix of land use transition between 2000 and 2010. Then, a linear interpolation algorithm is used to interpolate the land use demands in the 10 years before 2020 [41].

(2) Location Characteristics and Suitability

An empirical analysis is conducted to estimate the contributions of different location characteristics to the suitability of a specific type of land use by logistic regression [40]. The logistic regression is used to determine the probability that a certain grid cell is associated with a land use type given a set of potential driving factors [56]. These parameters generally consider demographic, socioeconomic, infrastructure, geomorphologic, and environmental variables [57]. In this study, 11 variables are selected, as shown in Figure 2: distance to the urban center, distance to district and county centers, distance to town centers, distance to highways and railways, distance to water, slope, aspect, elevation, population density, and GDP per capita. Moreover, the values of relative operating characteristics (ROCs) are used to validate the selected variables [55]. The spatial distributions of all land use types can be well explained by the selected driving variables, as indicated by the high ROC values (>0.7) [58].

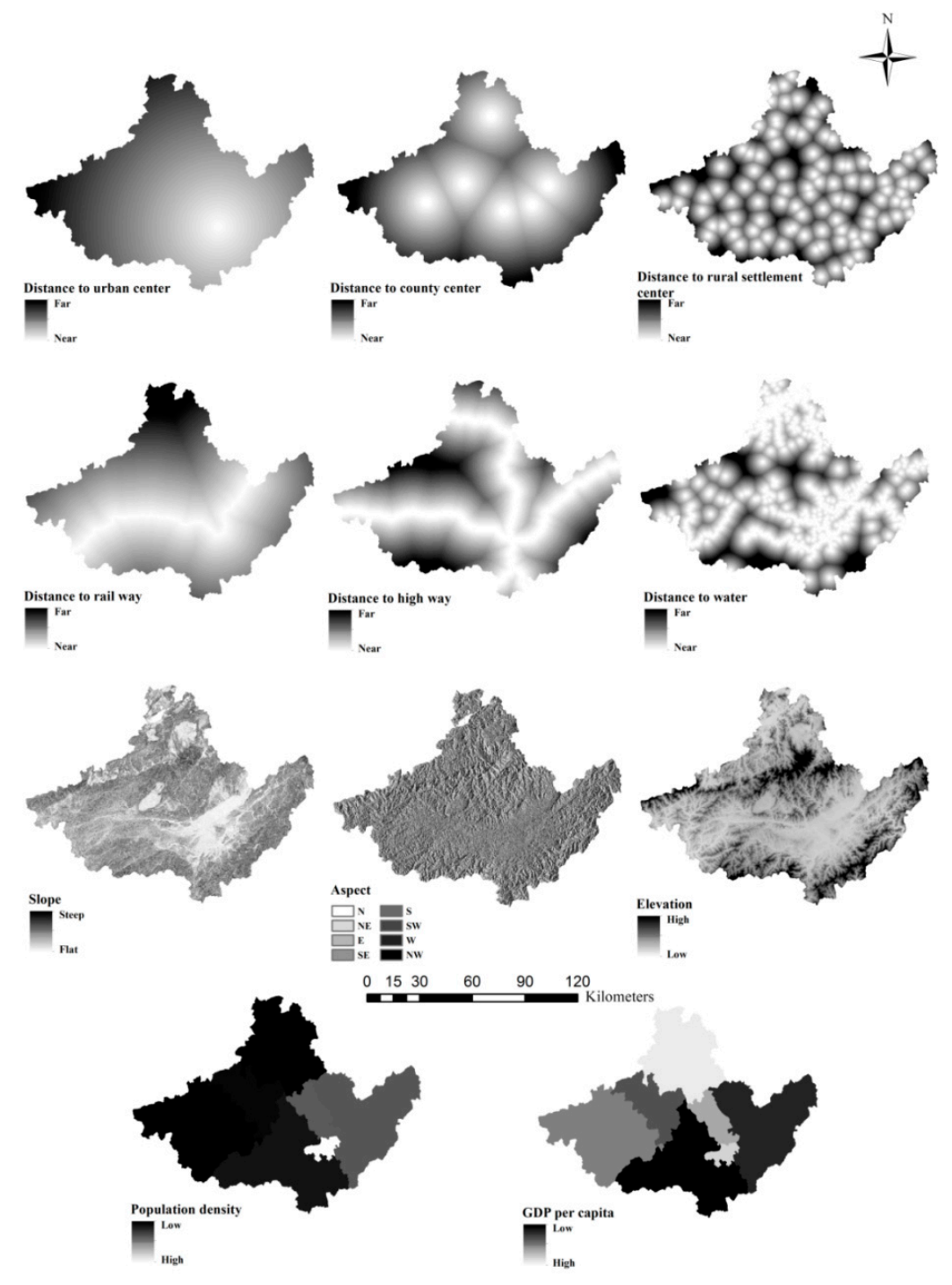

Figure 2. The selected driving factors of land use changes in the CLUE-S model. 
(3) The Specific Conversion Settings of Land Use Types

In each scenario, the specific conversion settings of land use types are defined and implemented based on the relative elasticity for change (ELAS) [59]. The relative elasticity ranges between 0 and 1 . The higher the defined elasticity is, the more difficult it is to convert that type of land use. Based on previous studies [54] and the specific requirements of each scenario in 2020, the ELAS values of each land use type are shown in Table 2.

Table 2. The ELAS values used in the CLUE-S model for two scenarios.

\begin{tabular}{cccccccc}
\hline Scenarios & Shrubland & Forest & Construction Land & Farmland & Grassland & Wetland & Bareland \\
\hline NTS & 0.6 & 0.7 & 1 & 0.5 & 0.4 & 0.4 & 0.7 \\
EPS & 0.7 & 0.8 & 0.9 & 0.5 & 0.5 & 0.9 & 0.3 \\
\hline
\end{tabular}

\subsubsection{Spatial Evaluation of Landscape Ecological Security}

\section{(1) Spatial Sampling}

The equally spaced sampling method is used to obtain units for evaluating landscape ecological security. Based on the extent of the study area, 423 units with square sample areas of $25 \mathrm{~km}^{2}$ are established, as shown in Figure 3. The value of the central point in each unit is regarded as the evaluated result of each sampling unit. The Kriging spatial interpolation technique is used to interpolate the value of each central point in the entire study area [60].

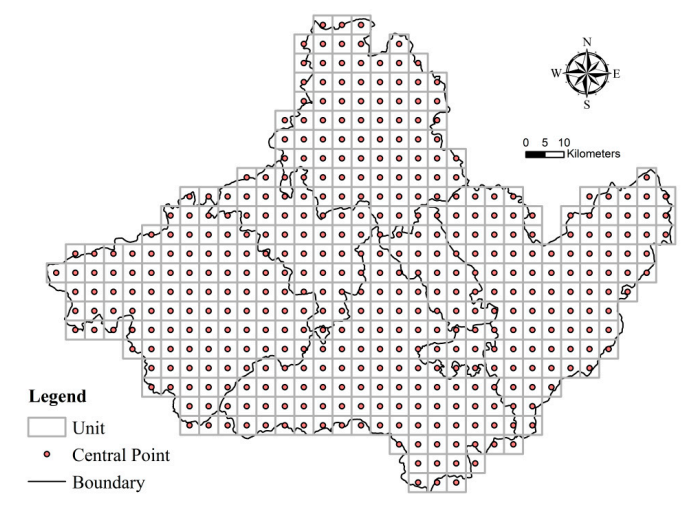

Figure 3. The evaluation units in the study area.

\section{(2) Pressure-State-Response Framework for Evaluating LES}

In this study, the P-S-R framework is applied to evaluate the landscape ecological security with three dimensions, the pressure of landscape change, the state of the landscape ecology system, and the human response to landscape change. Five indicators are selected for the analyses and spatially quantified, including the development intensity of construction land, population density, structure state, function state, and implementation degree of urban ecological function zoning [25,61]. Then, these indicators are divided into two types based on their effects on ecological security: positive factors $(+)$ and negative factors $(-)$. Table 3 provides the definitions and weights of the indicators. All weights proposed in this study are calculated using the Delphi method [62]. Eighteen experts were recruited to participate in the Delphi panel, including ten researchers from the Chinese Academy for Environmental Planning and universities (i.e., Fudan University, East China Normal University and HuangShan University), four policy makers from government agencies (i.e., Huangshan Environmental Protection Bureau and Huangshan Urban and Rural Planning Bureau), and four local residents. Four rounds were carried out to achieve a consensus among these experts. 
Urbanization is a spatial and temporal process related to land use transformation and population shifts from rural to urban areas [63]. The development intensity of construction land and the population density are selected as the pressure indicators in the P-S-R framework. The landscape structure, which includes various landscape parameters at multiple scales, and the landscape function, which is the capacity of a landscape ecosystem to provide sustainable resources and services to society, were defined as the basic characteristics of a landscape ecosystem [64]. Thus, the state of landscape ecological system in this study includes both structure and function states. The landscape structure state comprises the landscape disturbance degree and vulnerability degree. The degree of the disturbance is described by the landscape fragmentation, isolation, and dominance indices. Landscapes with high vulnerability are characterized by high risks of structure change and function loss in the face of external disturbances, especially anthropogenic activities $[65,66]$. The various values that define the landscape structure state are calculated according to the equations in Table 4 by FRAGSTATS [67], and all the landscape indices are normalized. In this study, fragmentation and isolation indices are calculated at the class level, and the dominance index is calculated at the landscape level. Based on the study of [68], the ecosystem service value of each land use type is selected to reflect the landscape function state.

In addition, due to the different units and magnitudes of the selected indicators in the P-S-R framework, the value of each indicator is standardized before calculating the associated value of landscape ecological security [69]. The LES equation is as follows:

$$
\text { LES }=\sum_{j=1}^{n} X_{j} \times w_{j}
$$

where LES is the landscape ecological security value, which ranges from 0 to $1 ; X_{j}$ is a standardized value of indicator $j ; w_{j}$ is the weight of indicator $j$; and $n$ is the number of selected indicators. 
Table 3. The indicators selected to evaluate landscape ecological security and their associated weights.

\begin{tabular}{|c|c|c|c|c|}
\hline Dimension (Weight) & \multicolumn{2}{|l|}{ Indicator (Weight) $( \pm)$} & Equation & Description \\
\hline \multirow[b]{2}{*}{$\begin{array}{l}\text { P-Pressure of landscape } \\
\text { change }(0.4)\end{array}$} & \multicolumn{2}{|c|}{ P1-Development intensity of construction land (0.6) (-) } & $\mathrm{U}_{(\mathrm{i}, \mathrm{j})}=\frac{\mathrm{S}_{\mathrm{B}_{\mathrm{i}, \mathrm{j}}}}{\mathrm{S}_{\mathrm{i}, \mathrm{j}}}$ & $\begin{array}{l}S_{B_{i j}} \text { is the construction land area and } S_{i, j} \text { is the total area } \\
\text { of the evaluation unit }(i, j) \text {. }\end{array}$ \\
\hline & \multicolumn{2}{|c|}{ P2-Population density $(0.4)(-)$} & $P_{d_{i}}=\frac{N_{i}}{S_{i}}$ & $\begin{array}{l}N_{i} \text { is the total population and } S_{i} \text { is the total area of the } \\
\text { i-th county. The value of each evaluation unit }(i, j) \text { is } \\
\text { obtained by interpolating the value of counties into the } \\
\text { entire study area. }\end{array}$ \\
\hline \multirow{2}{*}{$\begin{array}{l}\text { S-State of the landscape } \\
\text { ecological system }(0.5)\end{array}$} & S1-Structure state $(0.6)(-)$ & $\begin{array}{l}\text { Landscape disturbance degree } \\
\text { and vulnerability degree }\end{array}$ & $\operatorname{LSI}_{(\mathrm{i}, \mathrm{j})}=\sum_{\mathrm{i}=1}^{\mathrm{N}} \frac{\mathrm{A}_{\mathrm{ki}}}{\mathrm{A}_{\mathrm{k}}}\left(\mathrm{D}_{\mathrm{i}} \times \mathrm{V}_{\mathrm{i}}\right)$ & $\begin{array}{l}A_{k i} \text { is the area of the } i \text {-th landscape in the kth unit, } A_{k} \text { is } \\
\text { the area of the kth unit, } D_{i} \text { is the index of the landscape } \\
\text { disturbance degree of the i-th landscape, and } V_{i} \text { is the } \\
\text { vulnerability index of the i-th landscape. }\end{array}$ \\
\hline & S2-Function state $(0.4)(+)$ & Ecological service value & $\operatorname{ESV}_{(\mathrm{i}, \mathrm{j})}=\sum_{\mathrm{i}=1}^{\mathrm{n}} \mathrm{X}_{\mathrm{i}} \times \mathrm{V}_{\mathrm{i}}$ & $\begin{array}{l}X_{i} \text { is the area of the } i-t h \text { type of land use and } V_{i} \text { is the } \\
\text { ecosystem service value of the } i \text {-th type of land use. }\end{array}$ \\
\hline R-Human response $(0.1)$ & \multicolumn{2}{|c|}{ R-Implementation degree of the ecological function zoning $(1.0)(+)$} & \multicolumn{2}{|c|}{$\begin{array}{l}\text { This index is based on the eco-functional zoning in Huangshan City and values } \\
\text { recommended by researchers, urban administrators, and local residents using the Delphi } \\
\text { method (see Appendix A). }\end{array}$} \\
\hline
\end{tabular}

Table 4. Calculation methods for the landscape structure state.

\begin{tabular}{|c|c|c|}
\hline Name & Equation & Introduction \\
\hline Landscape disturbance degree & $\mathrm{D}_{\mathrm{i}}=\mathrm{w}_{1} \times \mathrm{F}_{\mathrm{i}}+\mathrm{w}_{2} \times \mathrm{I}_{\mathrm{i}}+\mathrm{w}_{3} \times \mathrm{DO}$ & \multirow{4}{*}{$\begin{array}{l}\mathrm{n}_{\mathrm{i}} \text { is the number of patches in the } \mathrm{i} \text {-th landscape, Ai is the area of the } \mathrm{i} \text {-th landscape, } \mathrm{A} \text { is the } \\
\text { area of all the landscapes, Pi is the proportion of the landscape occupied by the } \mathrm{i} \text {-th landscape } \\
\text { patch, and } \mathrm{m} \text { is the number of landscape classes. The weights of the landscape indices are } 0.5 \text {, } \\
0.3 \text {, and } 0.2 \text { for } \mathrm{w}_{1}, \mathrm{w}_{2} \text {, and } \mathrm{w}_{3} \text {, respectively [65]. }\end{array}$} \\
\hline Landscape fragmentation index & $\mathrm{F}_{\mathrm{i}}=\frac{\mathrm{n}_{\mathrm{i}}}{\mathrm{A}_{\mathrm{i}}}$ & \\
\hline Landscape isolation index & $\mathrm{I}_{\mathrm{i}}=\mathrm{A} \times \sqrt{\mathrm{n}_{\mathrm{i}} / \mathrm{A}} / 2 \mathrm{~A}_{\mathrm{i}}$ & \\
\hline Landscape dominance index & $\mathrm{DO}=-\sum_{\mathrm{i}=1}^{\mathrm{m}}\left(\mathrm{P}_{\mathrm{i}} \times \ln \mathrm{P}_{\mathrm{i}}\right)$ & \\
\hline Landscape vulnerability degree & $\begin{array}{l}\text { The associated values are as follows } \\
\text { and Bareland (0.7) }[70,71] .\end{array}$ & land (0.2), Forest (0.1), Construction land (0.6), Farmland (0.4), Grassland (0.3), Wetland (0.5), \\
\hline
\end{tabular}




\section{Results}

\subsection{Retrospective Analysis of Historic Land Use Change}

Retrospective analyses reveal the characteristics of historic land use change. Table 5 shows the transition matrix of land use change from 2000 to 2010 in our study area. Obvious conversions occurred between construction land and farmland, forestland and farmland, and shrubland and grassland. The area of construction land significantly increased by $58.59 \%$, and almost all of the increase was associated with conversion from farmland (4166.04 ha). This change may have been resulted from farmland acquisitions under the urbanization during this period. The area of forestland increased by 307.42 ha via farmland conversion. This change may have been influenced by the "Grain for Green" policy that was established in 1999, which encouraged the conversion of farmland to forestland for ecological restoration. Additionally, the area of grassland and wetland decreased by $6.73 \%$ and $1.17 \%$, respectively.

Table 5. The matrix of land use transition from 2000 to 2010 (unit: ha).

\begin{tabular}{|c|c|c|c|c|c|c|c|}
\hline 2010 & Shrubland & Forestland & $\begin{array}{l}\text { Construction } \\
\text { Land }\end{array}$ & Farmland & Grassland & Wetland & Bareland \\
\hline Forestland & 3.26 & $784,250.68$ & 32.88 & 12.27 & 0 & 4.06 & 0 \\
\hline Farmland & 81.25 & 288.07 & 4166.04 & $115,252.74$ & 0.17 & 732.50 & 0 \\
\hline Grassland & 1127.67 & 0.22 & 0.01 & 0.75 & $15,654.83$ & 0.46 & 0 \\
\hline Wetland & 0.00 & 0.15 & 17.04 & 896.00 & 0.01 & $14,123.65$ & 0 \\
\hline Bareland & 0 & 0 & 0.02 & 0 & 0 & 0 & 1392.63 \\
\hline
\end{tabular}

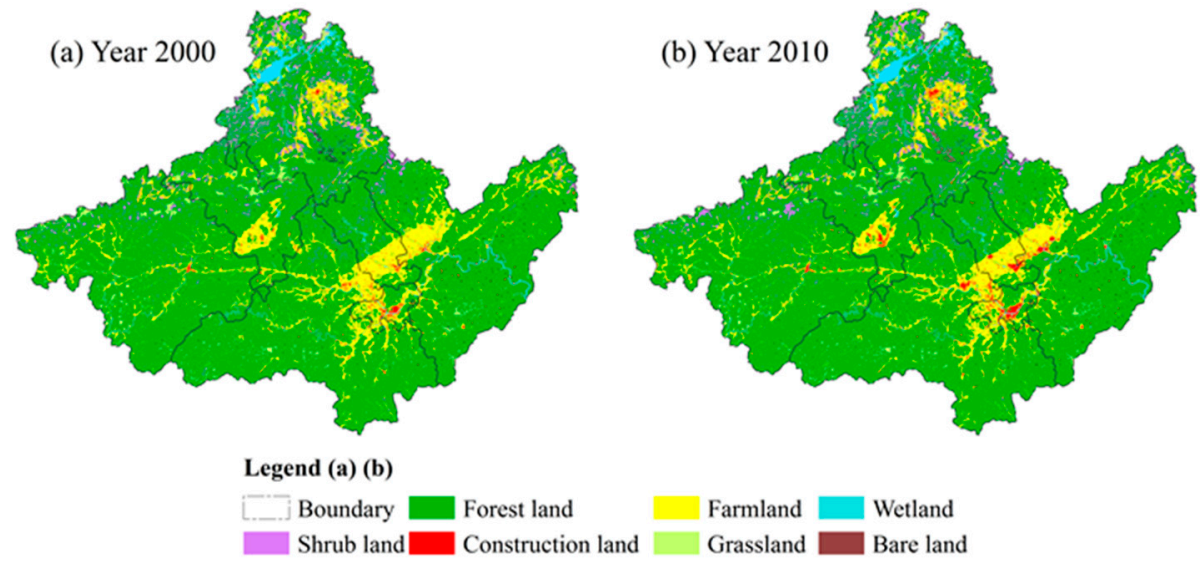

(c) Year 2000 to 2010

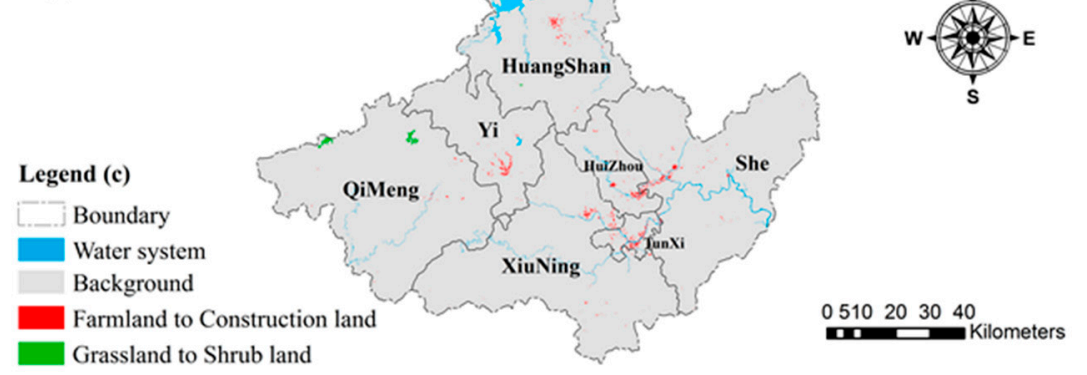

Figure 4. Spatial and temporal dynamics of land use change from 2000 to 2010 in Huangshan City.

The spatial dynamics of land use change from 2000 to 2010 are shown in Figure 4. The conversion from farmland to construction land mainly occurred in three highly urbanized regions: the central 
site, northern site, and western site. The central site encompasses the center of TunXi District (the administrative center) and its surrounding area, including southern HuiZhou District, eastern XiuNing County and western She County. The northern site is located in the center of HuangShan District, and the western site is located in the center of Yi County. In addition, the expansion of construction land was concentrated along the Xinanjiang River. Moreover, most conversion from grassland to shrubland occurred in the QiMeng District, and there was a small increase in construction land simultaneously. This observation reflects the spatial and temporal heterogeneity in land use change between districts and counties during the historical period.

\subsection{Spatial and Temporal Analysis of Land Use Simulation under Different Scenarios}

The ROC values and Kappa coefficient are calculated to assess the validity of the CLUE-S results. The ROC values of the logistic regression range between 0.783 and 0.977 , as shown in Table 6. Based on these values, the selected driving factors can effectively represent the location suitability for all land use types and can be further applied in the simulation of land use change. Additionally, a comparison of the simulated land use map and actual map from 2010 yielded a Kappa coefficient of 0.913 . This value suggests that the model exhibited satisfactory accuracy in simulating land use change and can be used to predict future land use in the study area.

Table 6. ROC values of the logistic regression.

\begin{tabular}{cccccccc}
\hline & Shrubland & Forestland & Construction Land & Farmland & Grassland & Wetland & Bareland \\
\hline ROC & 0.837 & 0.783 & 0.876 & 0.868 & 0.788 & 0.950 & 0.977 \\
\hline
\end{tabular}

Based on the land use change from 2000 to 2010, the Markov model and linear interpolation algorithm are used to predict the future demand associated with each land use type. Table 7 shows the demand variations of each land use type under different scenarios. A comparison of the NTS and EPS yielded significant differences in the demands for various land use types. Under the NTS, the trends from 2000 to 2010 remain the same for all land use types. Notably, the areas of construction land, forestland, and shrubland are projected to increase by $36.11 \%, 0.032 \%$, and $3.22 \%$, respectively, while the areas of farmland, grassland, and wetland will decrease accordingly. Additionally, the area of bareland remains constant. Under the EPS, the area of construction land will only increase by $10 \%$. Additionally, the forestland and shrubland areas will increase by $0.8 \%$ and $5.0 \%$, respectively, due to the "Grain for Green" policy. The wetland area will stop shrinking due to the prohibition of wetland conversion, and the area of bareland will considerably decrease due to the "Land Reclamation" policy.

Table 7. The land use demands in different scenarios (units: ha).

\begin{tabular}{|c|c|c|c|c|c|}
\hline \multirow{2}{*}{ Year Land Use Type } & \multirow{2}{*}{2010} & \multicolumn{2}{|c|}{2020} & \multicolumn{2}{|c|}{ Change Rate } \\
\hline & & NTS & EPS & NTS & EPS \\
\hline Shrubland & 33,512 & 34,580 & 35,180 & $3.22 \%$ & $5.0 \%$ \\
\hline Forestland & 784,423 & 784,709 & 790,637 & $0.032 \%$ & $0.8 \%$ \\
\hline Construction land & 11,385 & 15,490 & 12,523 & $36.11 \%$ & $10.0 \%$ \\
\hline Farmland & 116,338 & 112,113 & 109,357 & $-3.64 \%$ & $-6.0 \%$ \\
\hline Grassland & 15,712 & 14,653 & 14,924 & $-6.71 \%$ & $-5.0 \%$ \\
\hline Wetland & 14,842 & 14,665 & 14,842 & $-1.23 \%$ & $0.0 \%$ \\
\hline Bareland & 1389 & 1389 & 138 & $0.0 \%$ & $-90.0 \%$ \\
\hline
\end{tabular}

The spatial distribution of simulated land use in 2020 is shown in Figure 5 for both scenarios. Under the NTS (Figure 5a), construction land is concentrated in several previously urbanized areas, especially in the center of TunXi District where the construction land gradually encroaches upon the surrounding forestland and farmland. This might cause fragmentation and isolation of the ecological 
landscape. Meanwhile, construction land will continue to expand along the Xinanjiang River. Under the EPS (Figure 5b), construction land will moderately expand around the original urban area. Bareland, which is concentrated in the north-central portion of the study area, will be significantly transformed to forestland or shrubland. By overlaying the land use maps of the NTS and EPS scenarios, Figure 5c shows that under the NTS, more forestland will be transformed to farmland around Taiping Lake and more construction land expansion will occur in TunXi District and the water protection region.
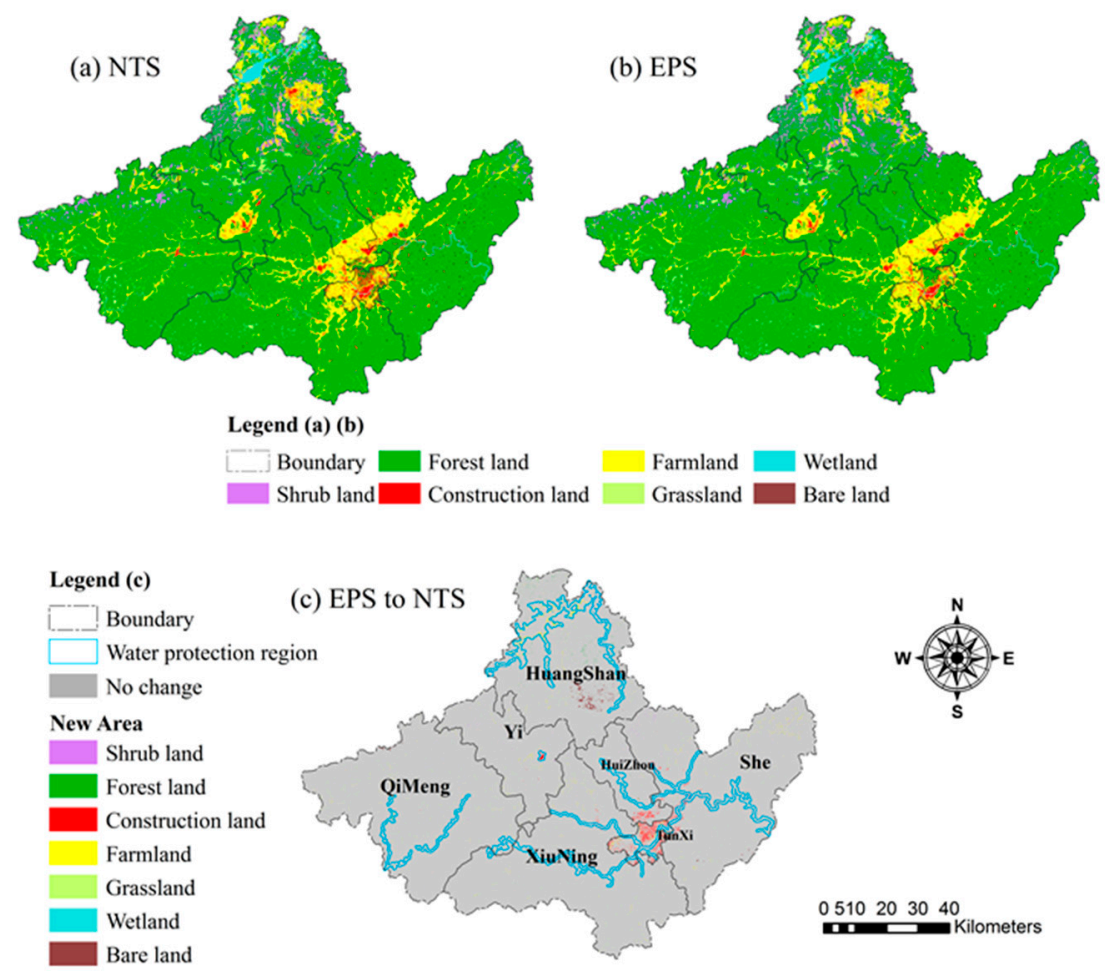

Figure 5. The spatial distributions of simulated land use in 2020 under different scenarios and a scenario comparison.

\subsection{Spatial and Temporal Changes in Landscape Ecological Security Based on the P-S-R Framework}

\subsubsection{Analysis of the Pressure, State, and Response of Ecological Security}

The P-S-R framework is used to assess the effects of land use change on landscape ecological security by investigating the pressure (development intensity of construction land and population density), state (landscape structure and function state), and response (implementation degree of ecological function zoning) of landscape ecological security in Huangshan City. Based on the results, a classification is established with five equal intervals between the minimum and maximum cell values. These intervals are labeled in increasing order as follows: extremely low, low, medium, high, and extremely high.

Figure 6 shows the spatial variations in landscape ecological security based on the P-S-R framework in Huangshan City from 2000 to 2020. Although the pressure associated with landscape ecological security generally remains at a low level, it exhibits clear spatial heterogeneity. The pressure increases in highly urbanized areas, especially in the center of TunXi District. This might be associated with urban sprawl, the expansion of construction land, and population growth. The state of landscape ecological security generally remains at a high level, except in the three highly urbanized areas. The relatively low level of the state of landscape ecological security in these areas might be associated with the fragmentation and isolation of the ecological landscape, as well as the loss of landscapes with high-value ecological services during the process of urbanization. Moreover, the overall response level 
gradually increases from 2000 to 2020, and areas with the large increase in high response level are likely due to the increased awareness regarding environmental protection.

(a) Year 2000

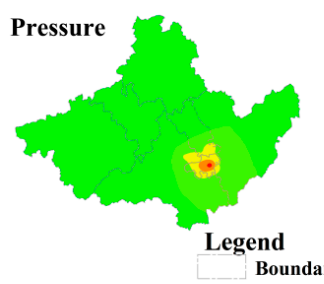

(b) Year 2010

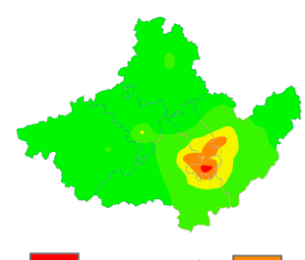

(c) Year 2020 NTS

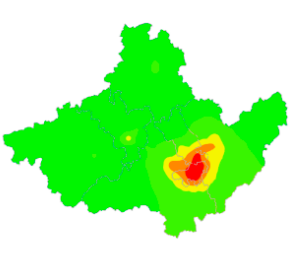

High $\square$ Medium $\square$ Low $\square$ Extremely low
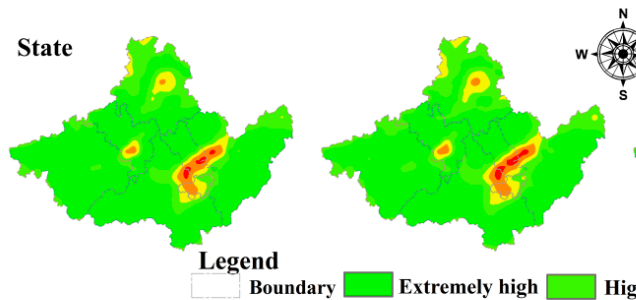

(d) Year 2020 EPS
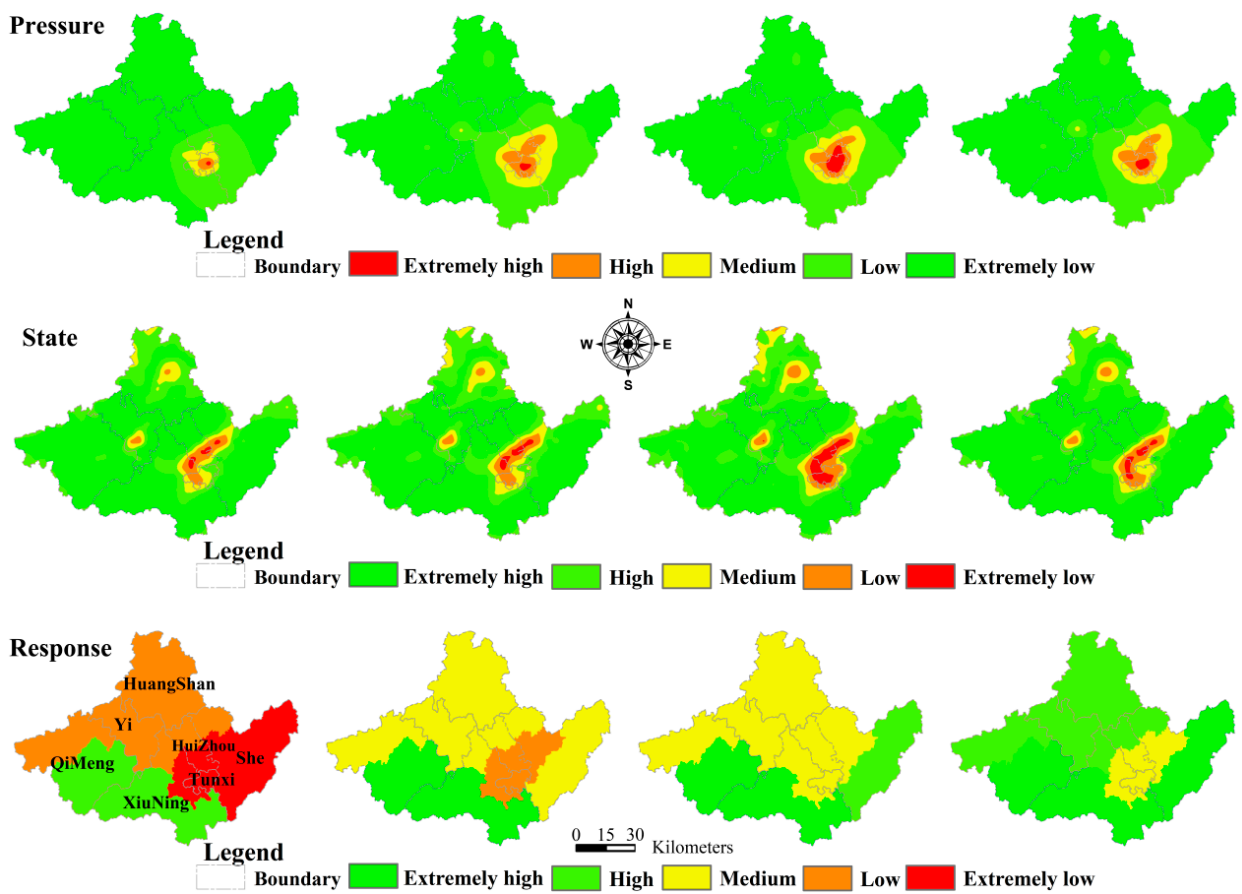

Figure 6. The spatial variations in landscape ecological security based on the P-S-R framework in Huangshan City.

Under the EPS, the areas with extremely high levels of pressure will decrease in 2020, especially in the urban center. Controlling urban expansion can reduce the pressure of human activities on ecosystems. The areas with state levels categorized as extremely high will substantially increase under the EPS, mainly in the area surrounding Taiping Lake and the northern-central parts of the city, where a large number of bareland was originally concentrated. Our results suggest that the state policies such as "Grain for Green" and "Land Reclamation", as well as several water resource protection projects, effectively promote landscape recovery from fragmentation and improve the landscape ecosystem services.

\subsubsection{Spatial and Temporal Analyses of Landscape Ecological Security under Different Scenarios}

The temporal variations in landscape ecological security are analyzed under different scenarios from 2000 to 2020. As shown in Table 8, although the average value of LES slightly decreases, obvious variations are observed in the area percentages of different security levels from 2000 to 2010. The areas of high and extremely high security levels decrease, while the areas of low and extremely low security levels increase, which result in an overall decline in the level of landscape ecological security in the study area. Under the future scenarios of NTS and EPS, the average values of LES are 0.748 and 0.767 , respectively. The relatively high LES under the ecological protection scenario is mainly caused by the significant increase in the percentage of the extremely high level from $45.40 \%$ to $54.84 \%$, as well as the decrease in the percentage of the extremely low level from $0.73 \%$ to $0.07 \%$. 
Table 8. The LES values in different years and scenarios.

\begin{tabular}{cccccccc}
\hline \multirow{2}{*}{ Year } & Scenario & $\begin{array}{c}\text { Average Value } \\
\text { (No Units) }\end{array}$ & Extremely Low & \multicolumn{3}{c}{ Area Percentage (Unit: \%) } \\
& & 0.760 & 0 & 2.34 & 5.35 & 49.32 & Medium \\
\hline 2000 & & 0.751 & 0.1 & 3.58 & 5.92 & 49.27 & 42.99 \\
2010 & & 0.748 & 0.73 & 3.92 & 5.43 & 44.51 & 45.40 \\
\hline \multirow{2}{*}{2020} & NTS & 0.07 & 3.79 & 5.06 & 36.25 & 54.84 \\
& EPS & 0.767 & & & & \\
\hline
\end{tabular}

The spatial variations in the level of landscape ecological security in our study area from 2000 to 2020 are shown in Figure 7. Although the LES generally remains at a high level, obvious spatial variations exist. Most western portions of the study area are classified as extremely high levels of security, as these hilly areas are unsuitable for urban development and water resource policies limit human activities. Unfortunately, low levels of security occur in the three highly urbanized areas (see Section 3.1), especially in the city center, which has a relatively low LES. As shown in Figure 7a,b, little variations occur in these areas from 2000 to 2010. An area with an extremely low security level is observed in the city center, and the total area of the low security level increases in 2010. Meanwhile, the area of the extremely high security level expanded in the eastern parts of the city, potentially because of the implementation of urban ecological function zoning.

Under the NTS, the area of the extremely low security level will expand to cover almost all TunXi District in 2020 due to the distinct increase in LES pressure, as shown in Figure 7c. TunXi district and the surrounding area may face serious ecological security issues in the future if no measures are adopted to improve the ecological security. Under the EPS, the area of the extremely high security level will increase in the northern, north-central, and eastern parts of the city, as shown in Figure $7 \mathrm{~d}$. This increase may be caused by restricting land use conversion and bareland reclamation near Taiping Lake. The area of the extremely low security level clearly decreases in TunXi District under the EPS compared to that under the NTS. This might suggest that controlling rapid urbanization can reduce the degeneration of regional ecological security.

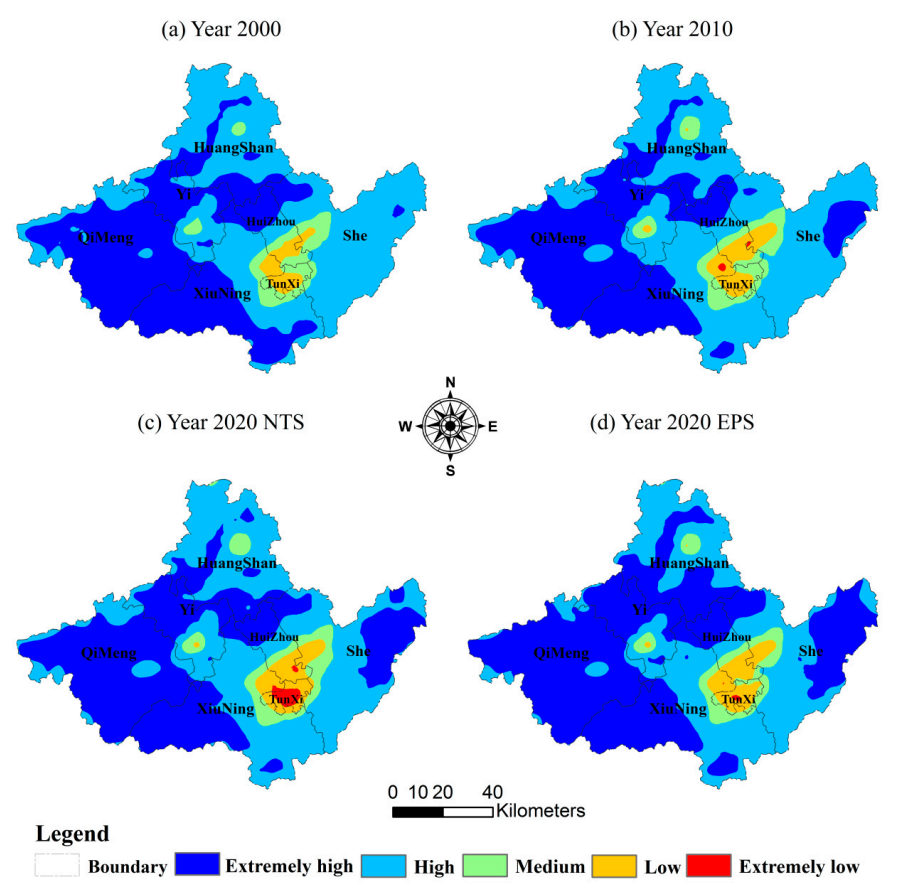

Figure 7. Spatial variations in the level of landscape ecological security in Huangshan City. 


\section{Discussion}

\subsection{The Integrated Method of Ecological Security Evaluation}

General methods of ecological security research have focused on detecting trends according to historical development [72,73]. Currently, relevant forecasting studies of ecological security are limited [30,74], while the uncertainty and dynamics of urban ecosystems must be considered. Our study explores the uncertainty and dynamics of urban ecological security by providing alternative future scenarios of urban development. CLUE-S provides a comprehensive understanding of the processes that determine changes in the spatial patterns of land use and explores future land use change [31]. Two land use scenarios are simulated based on CLUE-S in our study. It should be noted that various state policies, including "Grain for Green", "Land Reclamation", and several water resource protection policies, have been emphasized under the EPS in this study. These policies slow the rate of urbanization and protect key ecological resources such as forestland and wetland. Thus, analyzing such policies could create an optimal distribution of land use in a city. Moreover, we assess ecological security at the landscape scale rather than at the national or regional scale $[28,75,76]$. Additionally, rather than using a single landscape fragmentation indicator $[77,78]$ or complex but ineffective socioeconomic statistical indicators that are spatially averaged $[79,80]$, we develop a holistic indicator system using the P-S-R framework to evaluate ecological security based on landscape theory and spatial analysis. Various elements, including construction land development, population density change, and the implementation of eco-function zoning are included in our evaluation system to emphasize the dominant effects of human activities in urban areas. Spatial analyses of landscape pattern indices are combined with simulations of land use change to illustrate the spatio-temporal dynamics of ecological security variations.

Overall, the integrated method proposed in this study has two advantages for ecological security evaluation. First, simulating land use scenarios by using the CLUE-S model provides an alternative assessment for future urban development. Second, the integration of landscape pattern indices in the P-S-R framework can visually reveal the anthropogenic impacts on the internal structures and functions of ecological systems by differentiating among causes, effects, and human responses at the landscape scale. However, additional studies must be performed to improve the accuracy of population density estimation and to integrate more response indicators into the evaluation system in the P-S-R framework. Natural disturbances, e.g., climate change, should also be included in the evaluation for long-term prediction and evaluation. Furthermore, the nonlinear relationship among the pressure, state, and response should be considered in future studies.

\subsection{Implications of the Spatio-Temporal Dynamics of Ecological Security under Different Scenarios}

The rapid urbanization has resulted in considerable environmental and ecological problems worldwide [81,82]. A considerable number of studies have focused on characterizing the ecological consequences of urbanization, such as the effects on land quality [83], water quality [84], biodiversity [85], soil sealing [86], and greenhouse gas emission [87]. In this study, a synthetic method is proposed to quantify the complex relationship between urbanization and ecological security. Our results indicate that the dynamics of landscape ecological security are closely related to the process of urbanization and the associated land use change in Huangshan City. High pressure and low state regions of landscape ecological security are mainly concentrated in highly urbanized areas, especially in the city center. The rapid expansions of construction land and population growth in the process of urbanization have caused landscape fragmentation and habitat isolation, which was also suggested by other studies $[79,88]$. Meanwhile, these processes increase the pressure on the stability of the landscape structure and function, weaken the ability of the landscape ecosystem to resist external disturbances, and ultimately decrease the regional ecological security in urbanized areas. As such, optimizing the configuration and distribution of land use and landscape patterns is essential for improving the regional ecological security [18]. However, it is reported that the city proper dominated 
by an aggregated urban growth pattern has a relatively smaller impact on ecosystem fragmentation and service than the surrounding region dominated by a leapfrog or a liner growth pattern [89].

The spatial heterogeneity of ecological security exits between regions and this should be considered in future urban planning. The area of insecurity and rapid degradation are mainly located industrial development area [25] and densely populated area [90]. In our study area, QiMeng County, Yi County, and Huangshan District, which are located in the northwestern part of the city, generally remain at a high level of landscape ecological security, as shown in Figure 8. Other districts and counties, especially TunXi District, remain at a low level of landscape ecological security in 2020. Thus, the regional ecological security must be addressed in these areas. Urban planning should consider the spatial heterogeneities in ecological security to balance development in districts and counties and decrease ecological security degradation in densely populated and urbanized areas. For example, we assume low rates of construction land expansion and population growth in TunXi District in 2020 under the environmental protection scenario in our study. As a result, the landscape ecological security in the entire region is distinctly improved, and less area is classified as an extremely low level of ecological security. This information is of great significance to decision-makers for future urban planning and management.

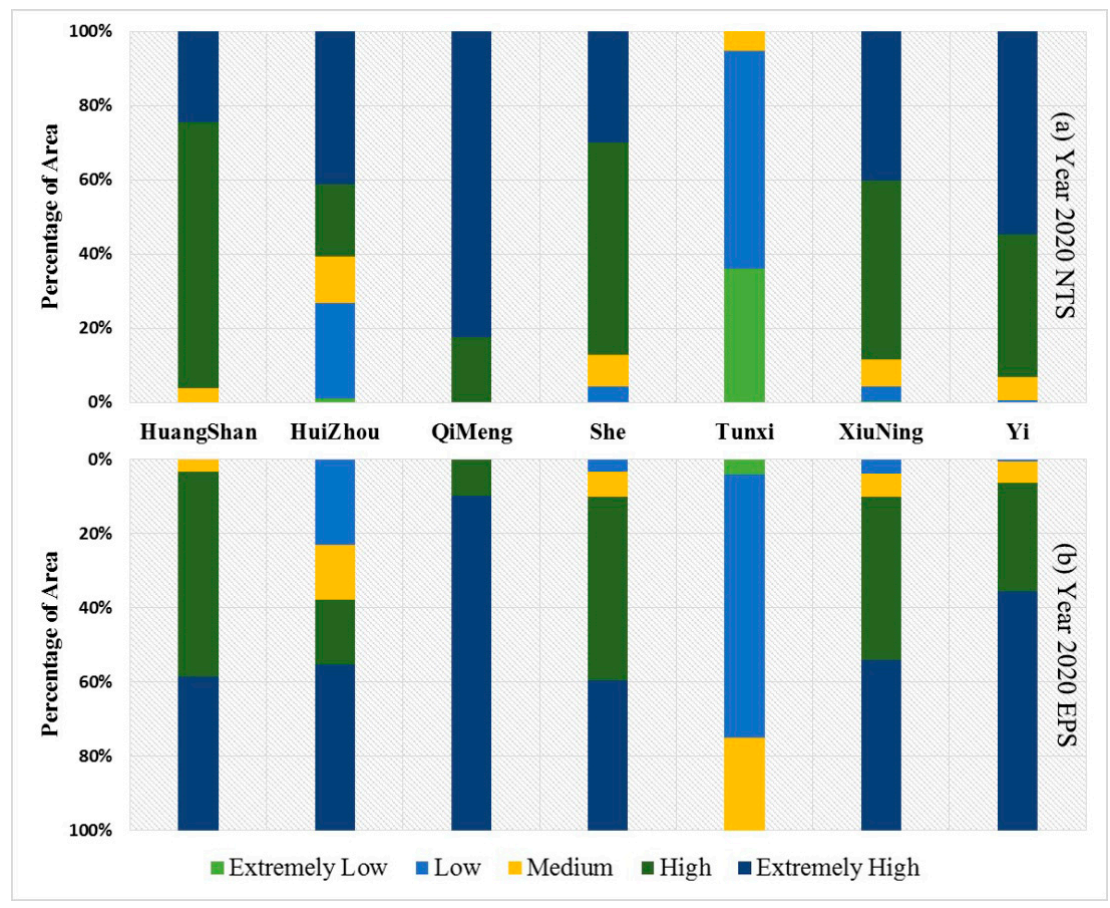

Figure 8. A comparison of landscape ecological security between the districts and counties under different scenarios in 2020.

\section{Conclusions}

In this study, the spatial and temporal dynamics of landscape ecological security in Huangshan City are evaluated using the proposed integrated method under different scenarios. The integrated method provides a predictable, causal, and visual evaluation of regional ecological security based on a multiple land use simulation using the CLUE-S model, a multi-variable analysis using the P-S-R framework, and a spatial analysis based on selected indicators of landscape patterns. The integrated method reveals the dynamic changes in ecological security and provides an alternative viewpoint to support decision making and future urban development.

The evaluation results suggest that an overall decline in ecological security will occur in the future based on the increase in the total area classified as an extremely low level of security. This decline is 
closely associated with urbanization and the associated land use changes. The urbanization intensity differences between regions result in spatial variations in ecological security, as confirmed by our analysis of ecological security at the administrative division level. TunXi District and the surrounding area, which have experienced relatively rapid urbanization, will potentially face serious ecological security issues in the future. Therefore, reasonable and appropriate measures must be established via future urban planning and management to reverse the decline in ecological security in the city and address the imbalance between regions. Under the ecological protection scenario proposed in this study, the ecological security levels of the city and TunXi District tend to be improved. The implication of importance of future ecological protection can greatly benefit future urban planning.

Acknowledgments: This work was financially supported by the National Key Research and Development Program of China (No. 2016YFC0502705), the National Natural Science Foundation of China (No. 41501194) and the Major Program of National Social Science Foundation of China (No. 14ZDB140). The research was completed also with support from the Department of Environmental Protection, Huangshan City and the Chinese Academy for Environmental Planning. The language of manuscript was revised by American Journal Experts (AJE).

Author Contributions: Yi Lu and Xiangrong Wang conceived and designed the experiments; Yi Lu performed the experiments; Yi Lu analyzed the data; Kun Li and Yiyang Xu contributed reagents/materials/analysis tools; and $\mathrm{Yi} \mathrm{Lu}$ and Yujing Xie wrote the paper.

Conflicts of Interest: The authors declare no conflict of interest.

\section{Appendix A}

Table A1. Implement degree of ecological function zoning in Huangshan City.

\begin{tabular}{cccccc}
\hline Ecological Function Zoning & \multicolumn{4}{c}{ Change in the Implementation Degree Index } \\
& $\mathbf{2 0 0 0}$ & $\mathbf{2 0 1 0}$ & $\mathbf{2 0 2 0}$ NTS & 2020 EPS \\
\hline Ecological headwater protection zone & 0.7 & 0.8 & 0.9 & 1 \\
Ecological environmental resilience zone & 0 & 0.5 & 0.7 & 0.9 \\
Ecological tourism development zone & 0.3 & 0.4 & 0.5 & 0.6 \\
Ecological economic development zone & 0 & 0.3 & 0.4 & 0.5 \\
\hline
\end{tabular}

\section{References}

1. Kamusoko, C.; Aniya, M.; Adi, B.; Manjoro, M. Rural sustainability under threat in Zimbabwe-Simulation of future land use/cover changes in the Bindura district based on the Markov-cellular automata model. Appl. Geogr. 2009, 29, 435-447. [CrossRef]

2. Zhou, S.; Huang, Y.; Yu, B.; Wang, G. Effects of human activities on the eco-environment in the middle Heihe River Basin based on an extended environmental Kuznets curve model. Ecol. Eng. 2014, 76, 14-26. [CrossRef]

3. Long, H.; Liu, Y.; Hou, X.; Li, T.; Li, Y. Effects of land use transitions due to rapid urbanization on ecosystem services: Implications for urban planning in the new developing area of China. Habitat Int. 2014, 44, 536-544. [CrossRef]

4. Su, S.; Ma, X.; Xiao, R. Agricultural landscape pattern changes in response to urbanization at ecoregional scale. Ecol. Indic. 2014, 40, 10-18. [CrossRef]

5. Kalnay, E.; Cai, M. Impact of urbanization and land-use change on climate. Nature 2003, 423, 528-531. [CrossRef] [PubMed]

6. Huong, H.T.L.; Pathirana, A. Urbanization and climate change impacts on future urban flooding in Can Tho city, Vietnam. Hydrol. Earth Syst. Sc. 2013, 17, 379-394. [CrossRef]

7. Ren, W.; Zhong, Y.; Meligrana, J.; Anderson, B.; Watt, W.E.; Chen, J.; Leung, H.-L. Urbanization, land use, and water quality in Shanghai: 1947-1996. Environ. Int. 2003, 29, 649-659. [CrossRef]

8. Yue, T.X.; Liu, J.Y.; Jørgensen, S.E.; Ye, Q.H. Landscape change detection of the newly created wetland in Yellow River Delta. Ecol. Model. 2003, 164, 21-31. [CrossRef] 
9. Solovjova, N.V. Synthesis of ecosystemic and ecoscreening modelling in solving problems of ecological safety. Ecol. Model. 1999, 124, 1-10. [CrossRef]

10. Cen, X.; Wu, C.; Xing, X.; Fang, M.; Garang, Z.; Wu, Y. Coupling intensive land use and landscape ecological security for urban sustainability: An integrated socioeconomic data and spatial metrics analysis in Hangzhou city. Sustainability 2015, 7, 1459-1482. [CrossRef]

11. Ezeonu, I.C.; Ezeonu, F.C. The environment and global security. Environmentalist 2000, 20, 41-48. [CrossRef]

12. Carr Edward, R. Human Ecological Security in Coastal Ghana, West Africa: The Social Implications of Economic and Environmental Change in Development Contexts; University of Kentucky: Lexington, KY, USA, 2002.

13. Costanza, R.; Norton, B.G.; Haskell, B.D. Ecosystem Health: New Goals for Environmental Management; Island Press: Washington, DC, USA, 1992.

14. Yang, G.; Wu, Z.; Lou, Q.; Huang, H.; Cheng, J.; Chen, Z. Landscape ecological security assessment based on projection pursuit in Pearl River Delta. Environ. Monit. Assess. 2012, 184, 2307-2319.

15. Zhang, R.; Pu, L.; Li, J.; Jing, Z.; Yan, X. Landscape ecological security response to land use change in the tidal flat reclamation zone, china. Environ. Monit. Assess. 2016, 188, 1-10. [CrossRef] [PubMed]

16. Dobson, A.P.; Bradshaw, A.; Baker, A.Á. Hopes for the future: Restoration ecology and conservation biology. Science 1997, 277, 515-522. [CrossRef]

17. Gao, X.; Feng, Z.; Ge, J. Analysis of landscape security pattern in western mountains of Shijiazhuang. Proc. SPIE 2008, 7145, 71451-71458.

18. Xu, L.; Hao, Y.; Li, Z.; Li, S. Land ecological security evaluation of Guangzhou, China. Int. J. Environ. Res. Public Health 2014, 11, 10537-10558. [CrossRef] [PubMed]

19. Yu, K. Security patterns and surface model in landscape ecological planning. Landsc. Urban Plan. 1996, 36, 1-17. [CrossRef]

20. Sunada, H. Landscape ecological approach to the relationships of land use patterns in watersheds to water quality characteristics. Landsc. Urban Plan. 2009, 92, 80-89.

21. Su, S.; Xiao, R.; Jiang, Z.; Zhang, Y. Characterizing landscape pattern and ecosystem service value changes for urbanization impacts at an eco-regional scale. Appl. Geogr. 2012, 34, 295-305. [CrossRef]

22. Deng, J.S.; Ke, W.; Yang, H.; Qi, J.G. Spatio-temporal dynamics and evolution of land use change and landscape pattern in response to rapid urbanization. Landsc. Urban Plan. 2009, 92, 187-198.

23. Bauer-Panskus, A.; Breckling, B.; Hamberger, S.; Then, C. Interactions of ecosystem properties, ecosystem integrity and ecosystem service indicators-A theoretical matrix exercise. Ecol. Indic. 2013, 28, 54-78.

24. Pinto, R.; Jonge, V.N.D.; Neto, J.M.; Domingos, T.; Marques, J.C.; Patrício, J. Towards a dpsir driven integration of ecological value, water uses and ecosystem services for estuarine systems. Ocean. Coast. Manag. 2013, 72, 64-79. [CrossRef]

25. Li, Y.; Sun, X.; Zhu, X.; Cao, H. An early warning method of landscape ecological security in rapid urbanizing coastal areas and its application in Xiamen, China. Ecol. Model. 2010, 221, 2251-2260. [CrossRef]

26. Sun, X.; Zhu, X.D. Landscape ecological security assessment in rapidly urbanizing bay-area: A case study of Xiamen city, China. Acta Ecol. Sin. 2008, 28, 3563-3573.

27. Sekovski, I.; Newton, A.; Dennison, W.C. Megacities in the coastal zone: Using a driver-pressure-stateimpact-response framework to address complex environmental problems. Estuar. Coast. Shelf Sci. 2012, 96, 48-59. [CrossRef]

28. Hodson, M.; Marvin, S. World Cities and Climate Change: Producing Urban Ecological Security; McGraw-Hill Education: New York, NY, USA, 2010.

29. Rees, W.E. Ecological footprints and appropriated carrying capacity: What urban economics leaves out. Environ. Urban. 1992, 4, 121-130. [CrossRef]

30. Gong, J.Z.; Liu, Y.S.; Xia, B.C.; Zhao, G.W. Urban ecological security assessment and forecasting, based on a cellular automata model: A case study of Guangzhou, China. Ecol. Model. 2009, 220, 3612-3620. [CrossRef]

31. Verburg, P.H.; Eickhout, B.; Meijl, H. A multi-scale, multi-model approach for analyzing the future dynamics of European land use. Ann. Reg. Sci. 2008, 42, 57-77. [CrossRef]

32. Jiang, W.; Chen, Z.; Lei, X.; He, B.; Jia, K.; Zhang, Y. Simulation of urban agglomeration ecosystem spatial distributions under different scenarios: A case study of the Changsha-Zhuzhou-Xiangtan urban agglomeration. Ecol. Eng. 2016, 88, 112-121. [CrossRef]

33. Yang, X.; Zheng, X.Q.; Chen, R. A land use change model: Integrating landscape pattern indexes and Markov-CA. Ecol. Model. 2014, 283, 1-7. [CrossRef] 
34. Wu, M.; Ren, X.; Yue, C.; Yang, K. A coupled SD and CLUE-S model for exploring the impact of land use change on ecosystem service value: A case study in Baoshan district, Shanghai, China. Environ. Manag. 2015, 56, 1-18. [CrossRef] [PubMed]

35. Luo, P.; Cao, X.; Li, H.; Li, M. Dynamic simulation of land use change in Shenzhen city based on Markov-logistic-CA models. In Proceedings of the 18th International Conference on Geoinformatics, Beijing, China, 18-20 June 2010; pp. 1-4.

36. Wehner, S.; Herrmann, S.; Berkhoff, K. Cluenaban-A land use change model combining social factors with physical landscape factors for a mountainous area in southwest China. Ecol. Indic. 2014, 36, 757-765. [CrossRef]

37. Overmars, K.P.; Verburg, P.H.; Veldkamp, T. Comparison of a deductive and an inductive approach to specify land suitability in a spatially explicit land use model. Land Use Policy 2007, 24, 584-599. [CrossRef]

38. Castella, J.-C.; Verburg, P.H. Combination of process-oriented and pattern-oriented models of land-use change in a mountain area of Vietnam. Ecol. Model. 2007, 202, 410-420. [CrossRef]

39. Dams, J.; Woldeamlak, S.; Batelaan, O. Predicting land-use change and its impact on the groundwater system of the Kleine Nete catchment, Belgium. Hydrol. Earth Syst. Sc. 2008, 12, 1369-1385. [CrossRef]

40. Verburg, P.H.; Overmars, K.P. Combining top-down and bottom-up dynamics in land use modeling: Exploring the future of abandoned farmlands in Europe with the dyna-clue model. Landsc. Ecol. 2009, 24, 1167-1181. [CrossRef]

41. Zhang, L.; Zhang, S.; Huang, Y.; Cao, M.; Huang, Y.; Zhang, H. Exploring an ecologically sustainable scheme for landscape restoration of abandoned mine land: Scenario-based simulation integrated linear programming and CLUE-S model. Int. J. Environ. Res. Public Health 2016, 13, 354. [CrossRef] [PubMed]

42. Zheng, H.W.; Shen, G.Q.; Wang, H.; Hong, J. Simulating land use change in urban renewal areas: A case study in Hong Kong. Habitat Int. 2015, 46, 23-34. [CrossRef]

43. The Department of Urban-Rural Planning Huangshan City. Integrated Land Use Planning of Huangshan City (2006-2020); The Department of Urban-Rural Planning Huangshan City: Huangshan, China, 2006.

44. Cui, S.Q.; Zhao, L.; Cheng-Wen, L.U. Land use change and its ecological effect in Huangshan city. Ecol. Sci. 2006, 25, 350-353.

45. Ministry of Environmental Protection of the China. Management of Ecological Environment Compensation in Xinan River Basin. Available online: http://wfs.mep.gov.cn/shj/sdsf/lybc/201308/t20130822_257932.htm (accessed on 22 August 2013). (In Chinese)

46. Ministry of Environmental Protection of the China. Ecological Environment Protection Planning of Lakes at Good Water Quality (2013-2020). Available online: http:/ /www.zhb.gov.cn/gkml/hbb/bwj/201409/ t20140930_289795.htm (accessed on 26 September 2014). (In Chinese)

47. The Office of Statistics Huangshan City. National Economy and Society Developed Statistical Bulletin of Huangshan City; The Office of Statistics Huangshan City: Huangshan, China, 2015.

48. Watson, R.T.; Noble, I.R.; Bolin, B.; Ravindranath, N.H.; Verardo, D.J.; Dokken, D.J. Land Use, Land-Use Change and Forestry: A Special Report of the Intergovernmental Panel on Climate Change; Cambridge University: Cambridge, UK, 2000; p. 333.

49. The Geospatial Data Cloud of the Chinese Academy of Science. DEM data of Huangshan City, China. Available online: http:/ / www.gscloud.cn (accessed on 5 April 2015).

50. The National Geometrics Center of China (NGCC). Administrative boundaries data of Huangshan City, China. Available online: http://ngcc.sbsm.gov.cn/ (accessed on 1 March 2015).

51. Swart, R.J.; Raskin, P.; Robinson, J. The problem of the future: Sustainability science and scenario analysis. Glob. Environ. Chang. 2004, 14, 137-146. [CrossRef]

52. Feng, Z.; Yang, Y.; Zhang, Y.; Zhang, P.; Li, Y. Grain-for-green policy and its impacts on grain supply in west china. Land Use Policy 2005, 22, 301-312. [CrossRef]

53. Ministry of Land and Resources. Land Reclamation. Available online: http://www.lcrc.org.cn/ (accessed on 5 August 2015).

54. Luo, G.; Yin, C.; Chen, X.; Xu, W.; Lu, L. Combining system dynamic model and CLUE-S model to improve land use scenario analyses at regional scale: A case study of sangong watershed in Xinjiang, China. Ecol. Complex. 2010, 7, 198-207. [CrossRef]

55. Pontius, R.G.; Schneider, L.C. Land-cover change model validation by an roc method for the Ipswich watershed, Massachusetts, USA. Agric. Ecosyst. Environ. 2001, 85, 239-248. [CrossRef] 
56. Verburg, P.H.; Soepboer, W.; Veldkamp, A.; Limpiada, R.; Espaldon, V.; Mastura, S.S.A. Modeling the spatial dynamics of regional land use: The CLUE-S model. Environ. Manag. 2002, 30, 391-405. [CrossRef] [PubMed]

57. Lin, Y.P.; Hong, N.M.; Wu, P.J.; Lin, C.J. Modeling and assessing land-use and hydrological processes to future land-use and climate change scenarios in watershed land-use planning. Environ. Geol. 2007, 53, 623-634. [CrossRef]

58. Chu, H.J.; Lin, Y.P.; Huang, C.W.; Hsu, C.Y.; Chen, H.Y. Modelling the hydrologic effects of dynamic land-use change using a distributed hydrologic model and a spatial land-use allocation model. Hydrol. Process. 2010, 24, 2538-2554. [CrossRef]

59. Verburg, P.H.; Schot, P.P.; Dijst, M.J.; Veldkamp, A. Land use change modelling: Current practice and research priorities. Geojournal 2004, 61, 309-324. [CrossRef]

60. Jia, Y.; Zhao, J.; Nan, Z.; Zhao, C.; Wang, S. Ecological safety assessment of grassland based on entropy-right method: A case study of Gansu pastoral area. Chin. J. Ecol. 2006, 25, 1003-1008.

61. Huang, H.F.; Kuo, J.; Lo, S.L. Review of psr framework and development of a dpsir model to assess greenhouse effect in Taiwan. Environ. Monit. Assess. 2011, 177, 623-635. [CrossRef] [PubMed]

62. Linstone, H.A.; Turoff, M. The delphi method: Techniques and applications. J. Market. Res. 1975, 18, 620.

63. United Nations. World Urbanization Prospects: The 2014 Revision (Highlights); United Nations: New York, NY, USA, 2014.

64. Rowe, J.S.; Sheard, J.W. Ecological land classification: A survey approach. Environ. Manag. 1981, 5, 451-464. [CrossRef]

65. Xie, H.; Wang, P.; Huang, H. Ecological risk assessment of land use change in the poyang lake eco-economic zone, China. Int. J. Environ. Res. Public Health 2013, 10, 328-346. [CrossRef] [PubMed]

66. Gong, J.; Yang, J.; Tang, W. Spatially explicit landscape-level ecological risks induced by land use and land cover change in a national ecologically representative region in China. Int. J. Environ. Res. Public Health 2015, 12, 14192-14215. [CrossRef] [PubMed]

67. McGarigal, K.S.; Cushman, S.A.; Neel, M.C.; Ene, E. Fragstats: Spatial Pattern Analysis Program for Categorical Maps. Available online: http:/ / www.umass.edu/landeco/research/fragstats/fragstats.html (accessed on 11 October 2016).

68. Xie, G.; Zhen, L.; Chunxia, L.U. Applying value transfer method for eco-service valuation in China. J. Resour. Ecol. 2010, 51-59.

69. Zhang, Z.; Lu, W.X.; Zhao, Y.; Song, W.B. Development tendency analysis and evaluation of the water ecological carrying capacity in the siping area of Jilin province in China based on system dynamics and analytic hierarchy process. Ecol. Model. 2014, 275, 9-21. [CrossRef]

70. Jiang, W.G.; Jing, L.I.; Jia Hong, L.I.; Xie, Z.R.; Wang, W.J. Assessment of wetland ecosystem health in the Liaohe River Delta. Acta Ecol. Sin. 2005, 25, 408-414.

71. Xie-Hui, L.I.; Jing-Yi, L.I. Analysis on regional landscape ecological risk based on GIS-A case study along the lower reaches of the Weihe river. Arid Zone Res. 2008, 25, 899-903.

72. Whitall, D.; Bricker, S.; Ferreira, J.; Nobre, A.M.; Simas, T.; Silva, M. Assessment of eutrophication in estuaries: Pressure-state-response and nitrogen source apportionment. Environ. Manag. 2007, 40, 678-690. [CrossRef] [PubMed]

73. Tegler, B.; Sharp, M.; Johnson, M.A. Ecological monitoring and assessment network's proposed core monitoring variables: An early warning of environmental change. Environ. Monit. Assess. 2001, 67, 29-55. [CrossRef] [PubMed]

74. Syphard, A.D.; Clarke, K.C.; Franklin, J. Using a cellular automaton model to forecast the effects of urban growth on habitat pattern in southern California. Ecol. Complex. 2005, 2, 185-203. [CrossRef]

75. Pirages, D.C.; DeGeest, T.M. Ecological Security: An Evolutionary Perspective on Globalization; Rowman \& Littlefield Publishers: Lanham, MD, USA, 2003.

76. Huang, Q.; Wang, R.; Ren, Z.; Li, J.; Zhang, H. Regional ecological security assessment based on long periods of ecological footprint analysis. Resour. Conserv. Recycl. 2007, 51, 24-41. [CrossRef]

77. Jaeger, J.A.; Bertiller, R.; Schwick, C.; Müller, K.; Steinmeier, C.; Ewald, K.C.; Ghazoul, J. Implementing landscape fragmentation as an indicator in the Swiss Monitoring System of Sustainable Development (MONET). J. Environ. Manag. 2008, 88, 737-751. [CrossRef] [PubMed] 
78. Girvetz, E.H.; Thorne, J.H.; Berry, A.M.; Jaeger, J.A. Integration of landscape fragmentation analysis into regional planning: A statewide multi-scale case study from California, USA. Landsc. Urban Plan. 2008, 86, 205-218. [CrossRef]

79. Hua, Y.; Yan, M.; Limin, D. Land ecological security assessment for bai autonomous prefecture of Dali based using PSR model-With data in 2009 as case. Energy Procedia 2011, 5, 2172-2177. [CrossRef]

80. Zhao, Y.-Z.; Zou, X.-Y.; Cheng, H.; Jia, H.-K.; Wu, Y.-Q.; Wang, G.-Y.; Zhang, C.-L.; Gao, S.-Y. Assessing the ecological security of the Tibetan plateau: Methodology and a case study for Lhaze County. J. Environ. Manag. 2006, 80, 120-131. [CrossRef] [PubMed]

81. Bhatta, B.; Saraswati, S.; Bandyopadhyay, D. Quantifying the degree-of-freedom, degree-of-sprawl, and degree-of-goodness of urban growth from remote sensing data. Appl. Geogr. 2010, 30, 96-111. [CrossRef]

82. Habibi, S.; Asadi, N. Causes, results and methods of controlling urban sprawl. Procedia Eng. 2011, 21, 133-141. [CrossRef]

83. Su, S.; Li, D.; Yu, X.; Zhang, Z.; Zhang, Q.; Xiao, R.; Zhi, J.; Wu, J. Assessing land ecological security in Shanghai (China) based on catastrophe theory. Stoch. Environ. Res. Risk Assess. 2011, 25, 737-746. [CrossRef]

84. Su, S.; Li, D.; Zhang, Q.; Xiao, R.; Huang, F.; Wu, J. Temporal trend and source apportionment of water pollution in different functional zones of Qiantang river, China. Water Res. 2011, 45, 1781-1795. [CrossRef] [PubMed]

85. Turner, M.G.; Gardner, R.H.; O’Neill, R.V. Landscape ecology in theory and practice. Geography 2002, 83, 479-494.

86. Su, S.; Zhang, Q.; Zhang, Z.; Zhi, J.; Wu, J. Rural settlement expansion and paddy soil loss across an ex-urbanizing watershed in eastern coastal China during market transition. Reg. Environ. Chang. 2011, 11, 651-662. [CrossRef]

87. Matteucci, S.D.; Morello, J. Environmental consequences of exurban expansion in an agricultural area: The case of the Argentinian Pampas ecoregion. Urban Ecosyst. 2009, 12, 287-310. [CrossRef]

88. Weng, Y.C. Spatiotemporal changes of landscape pattern in response to urbanization. Landsc. Urban Plan. 2007, 81, 341-353. [CrossRef]

89. Zhou, K.; Liu, Y.; Tan, R.; Song, Y. Urban dynamics, landscape ecological security, and policy implications: A case study from the Wuhan area of central China. Cities 2014, 41, 141-153. [CrossRef]

90. Di, G.M.; Holderegger, R.; Tobias, S. Effects of habitat and landscape fragmentation on humans and biodiversity in densely populated landscapes. J. Environ. Manag. 2009, 90, 2959-2968. 